\title{
Decision on the Boundary Stratotype for the Middle/Upper Devonian Series Boundary
}

\author{
by Gilbert Klapper, Raimund Feist and Michael R. House
}

(with comments by John W. Cowie)

\begin{abstract}
The Middle-Upper Devonian Series Global Stratotype Section and Point (GSSP), which defines the basal boundary of the Upper Devonian Series and the Frasnian Stage, has now been agreed upon. It is exposed at Col du Puech de la Suque section in the southeastern Montagne Noire, France. Full details are given in the following contribution. (J.W. Cowie, Chairman, International Commission on Stratigraphy)
\end{abstract}

\section{Middle/Upper Devonian Series Boundary}

The boundary between the Middle and Upper Devonian Series is coincident with the lower boundary of the Frasnian Stage. The exact position of the Series boundary was chosen by the Subcommission on Devonian Stratigraphy in 1982 to coincide with the lower boundary of the Lower asymmetricus Zone, defined by the first occurrence of Ancyrodella rotundiloba (Bryant) and referred to as the Lower asymmetricus Boundary. The Lower asymmetricus Zone is a zonal subdivision of the conodont standard zonation that was established in the early 1960s (Ziegler, 1962) and revised in the early 1970 s (Ziegler, 1971).

Boundary Stratotype

The stratotype of the Lower asymmetricus Boundary is in the exposure at $\mathrm{Col}$ du Puech de la Suque section $\mathrm{E}$ in the southeastern Montagne Noire, France (Fig. 1). The section is located on the eastern slope of the hill 358 , about $50 \mathrm{~m}$ ENE from the crest, at $1.1 \mathrm{~km}$ SE of St. Nazaire-de-Ladarez $(1: 25,000$ Sheet St. Chinian, $x=660.67, y=133.95)$. Col du Puech de la Suque section $E$ is primarily a natural outcrop (Fig. 2) that has been enhanced by excavation of some formerly covered beds; the sequence of beds is overturned, dipping about $60^{\circ}$ to the west.

Section $E$ is characterized by a sequence of predominantly red and grey pelagic calcilutites, punctuated by hardgrounds that are mainly in the part of the sequence above the boundary level (Fig. 3, and see Fig. 5 of Feist and Klapper, 1985). The section has been described in detail, including location maps, columnar diagrams and a section profile, by Feist and Klapper (1985, p. 3-5, Figs. 2 and 5), House and others (1985, p. 6, Figs. l and 2), and Klapper (1985, Fig. 2). The proposal that this be the boundary stratotype section for the Viddle/Upper Devonian Series boundary was published by Feist and others (in Ziegler and Werner, 1985).

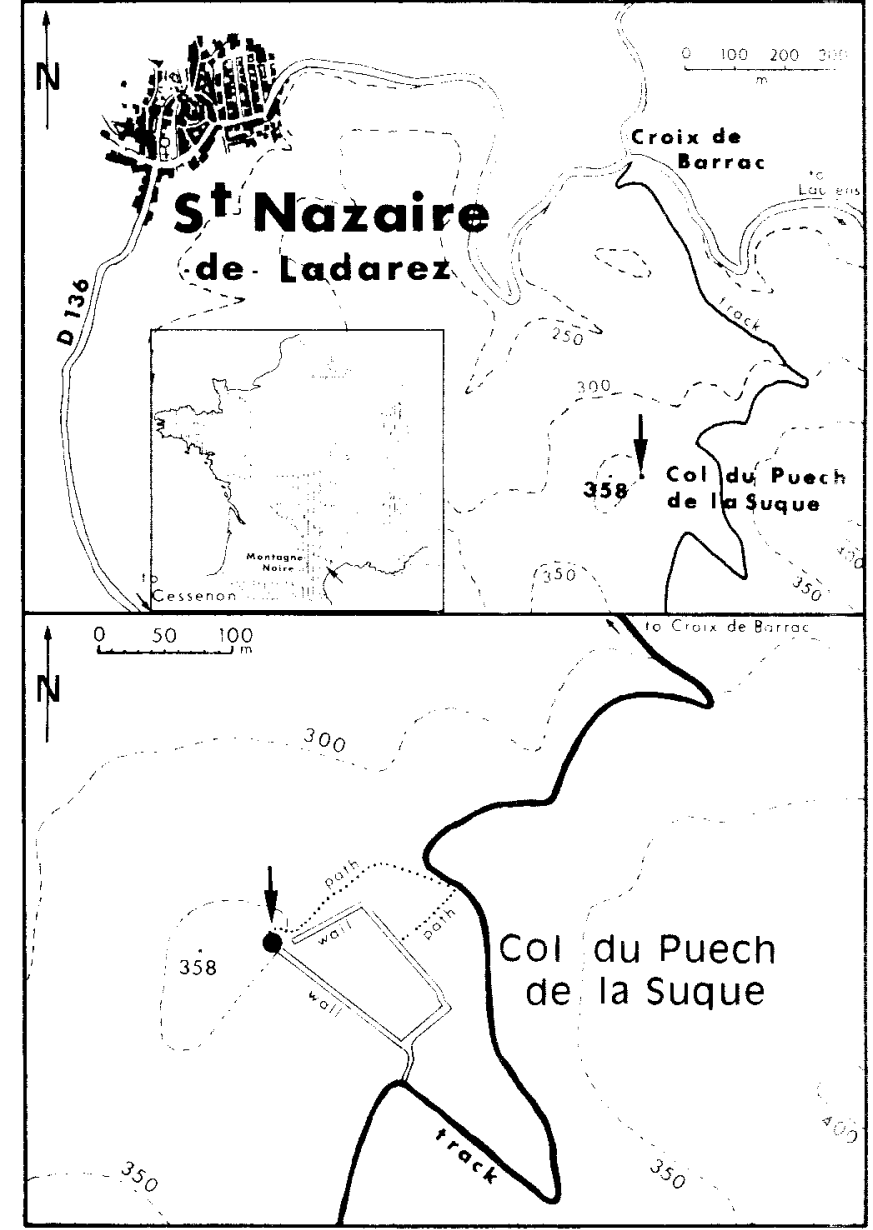

Figure 1: Location of the site of the boundara stratotype section for the Midale/upper Devoniar Series boundary, at col du Puech de la Suque, Franct. 


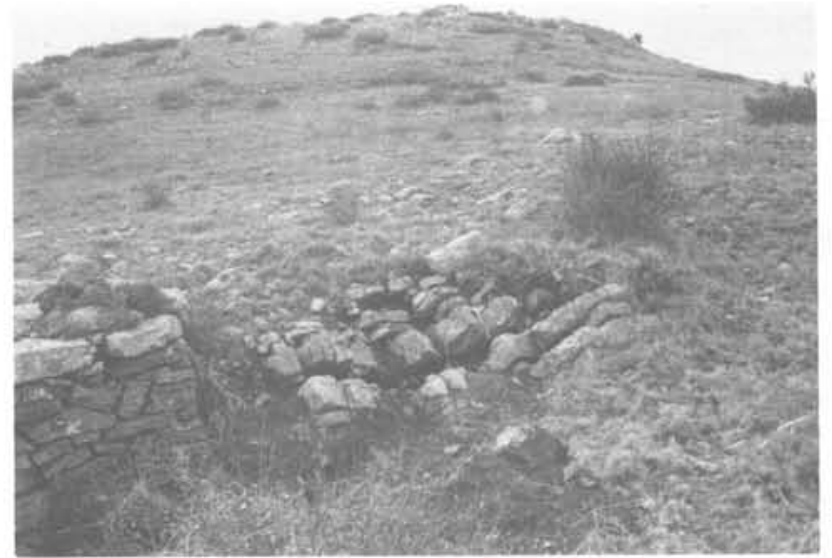

Figure 2: A. Stratotype section at Col du Puech de la suque section $B$ showing the boundary beds cropping out adjacent to the end of the wall on the eastern slope of hill 358 (in the background). Hammer is on beds 39-41. B. Close-up of overturned Middle/Upper Devonian Series boundary beds

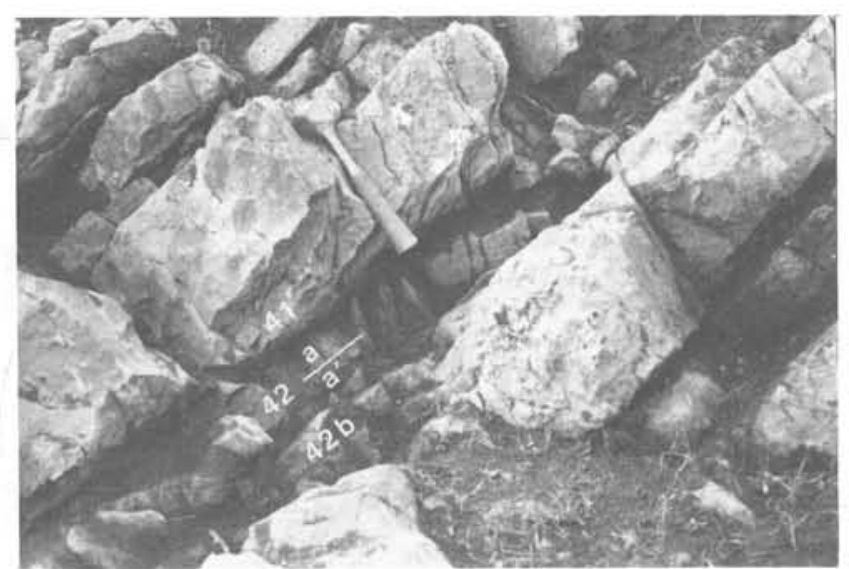

shown in $A$. The base of the Upper Devonian Series, the Frasnian Stage, and the Lower asymmetricus Zone is at the base of bed 42a'. Hammer $(28 \mathrm{~cm}$ long) is at same position as in $A$, and the end of its handle is slightly above the top of bed 41 .

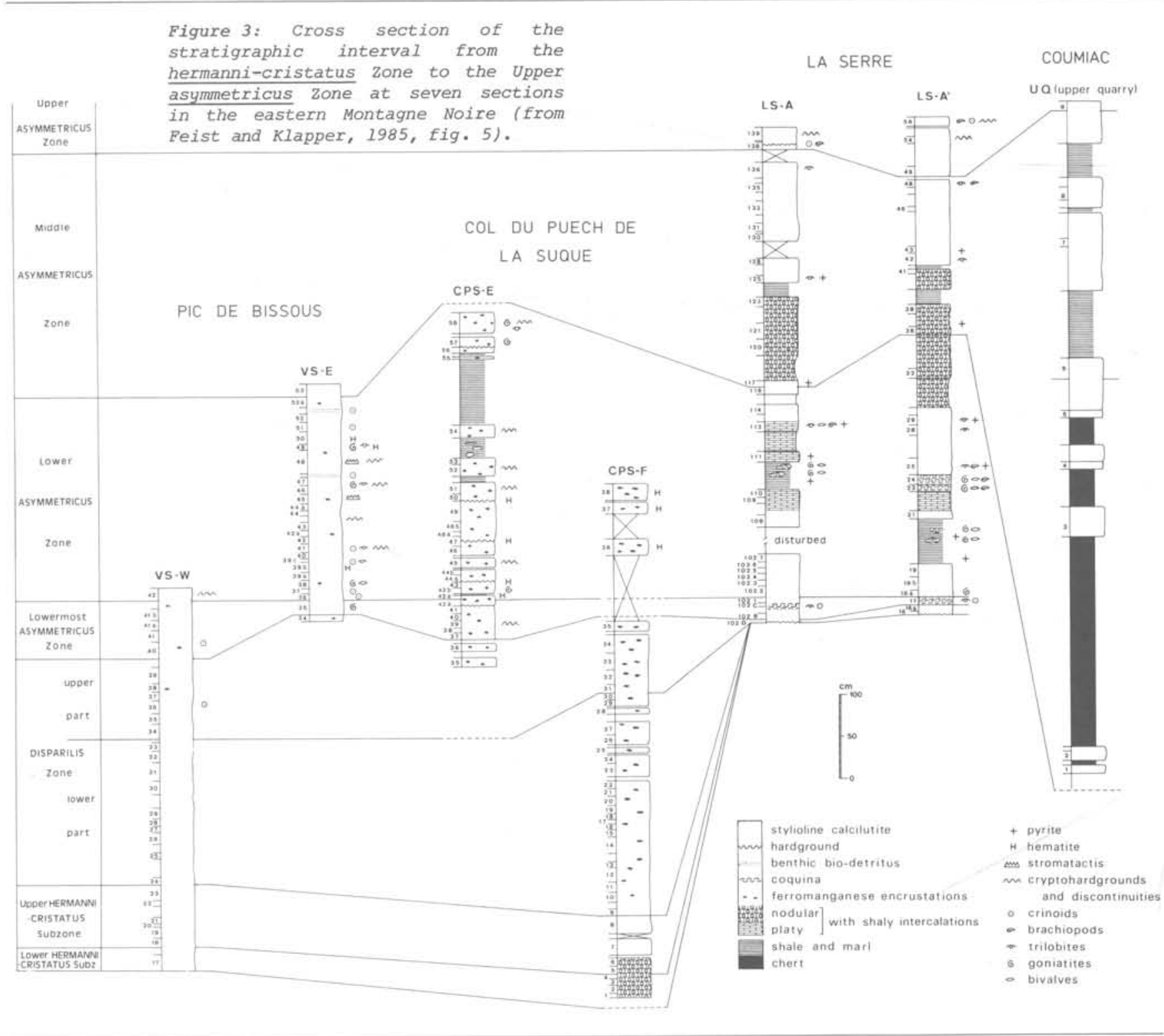


Col du Puech de la Suque section $E$ has been sampled for conodonts at a fine scale in a nearly continuous manner (Figs. 3, 4). The lowest occurrence of Ancyrodella rotundiloba is at a level $8-11 \mathrm{~cm}$ above the base of a $13-\mathrm{cm}$ bed, which was divided for sampling purposes into an $8-\mathrm{cm}$ thick bed (42a) and a 5-cm layer (42a'; Figs. 2, 4). There is no obvious hiatus, hardground, or sampling gap associated with the entry of Ancyrodella rotundiloba within the $13-\mathrm{cm}$ bed. The Global stratotype Section and Point (GSSP) is at the base of bed $42 \mathrm{a}^{\prime}$.

There is no problem of access to the section, either politically or logistically. The section is situated above an abandoned vineyard that is enclosed by thick, stone walls; it is adjacent to the northwestern corner of the enclosed area (Fig. 1). The land containing the stratotype section is owned by the commune of St. Nazaire-de-Ladarez and permission to visit the outcrop can be granted.

\section{Criteria for Recognition and Correlation of the Lower} Asymmetricus Boundary

The lowest occurrence of Ancyrodella rotundiloba defines the lower boundary of the Lower asymmetricus Zone. The predecessor species is interpreted to be Ancyrodella binodosa Uyeno (see Bultynck, 1982a; Ziegler and Klapper, 1985, p. 107), and its lowest occurrence is in the upper part of the subjacent Lowermost asymmetricus Zone, as developed for example in the Belgian and western Canadian sequences. Thus, the recognition of these two zones is supplementary to the identification of the Lower asymmetricus Boundary.

The Lowermost asymmetricus Zone in the Montagne Noire is characterized by a distinctive conodont association of Polygnathus norrisi, Polygnathus asymmetricus (in some sections), $P$. pennatus, $P$. collieri, and $P$. cristatus? (for detailed discussion, see Feist and Klapper, 1985, p. 12-15). All of these species are present in the zone at Col du Puech de la Suque section E (Fig. 4). The goniatite Pharciceras sp. occurs in the Lowermost asymmetricus Zone at the same section, and Pharciceras aff. kiliani, Ponticeras cf. kayseri, and Pseudoprobeloceras $\mathrm{cf}$. nebechense occur in the same zone at Pic de Bissous, VS- $W$, as documented by House and others (1985, Fig. 13; and see Fig. 5 this article).

The phylogenetic development of the early species of Ancyrodella within the Lower asymmetricus Zone in the Montagne Noire is the most detailed yet published (Klapper, 1985). Five associations are recognizable, in ascending order: 1) an interval in the lowest part of the zone characterized by the early form of Ancyrodella rotundiloba; 2) an interval with both early and late forms of A. rotundiloba; 3 ) an interval with the early form of A. alata and the late form of A. rotundiloba; 4) an interval with A. rugosa and the late forms of A. alata and A. rotundiloba; and 5 ) an interval with A. africana, A. pramosica, the late form of A. alata, and A. rugosa (only in the lower part). This sequence is well displayed at $\mathrm{Col}$ du Puech de la Suque section $\mathrm{E}$ and Pic de Bissous, VS-E (Klapper, 1985, Figs. 2 and 1, respectively). In addition to the phylogenetic development within the early species of Ancyrodella, a diverse sequence of species of Polygnathus, including those of the Palmatolepis biofacies, is well represented within the Lower asymmetricus Zone in the Montagne Noire (Klapper, 1985, Figs. 1 and 2; Feist and Klapper, 1985, Figs. 8 and 9).

Major segments of the Ancyrodella phylogeny have been found in the same order within the Lower asymmetricus Zone in Belgium (Bultynck, 1982b), New York (Kirchgasser et al., in Ziegler and Werner, 1985, Table 4), western Canada (Uyeno, 1974), and central Nevada (Johnson et al., in Ziegler and Werner, 1985 , Table 6 , but see version in Corrigenda). The occurrence of Ancyrodella rotundiloba itself is widespread in major Devonian sequences throughout the world (Bultynck, 1982a).

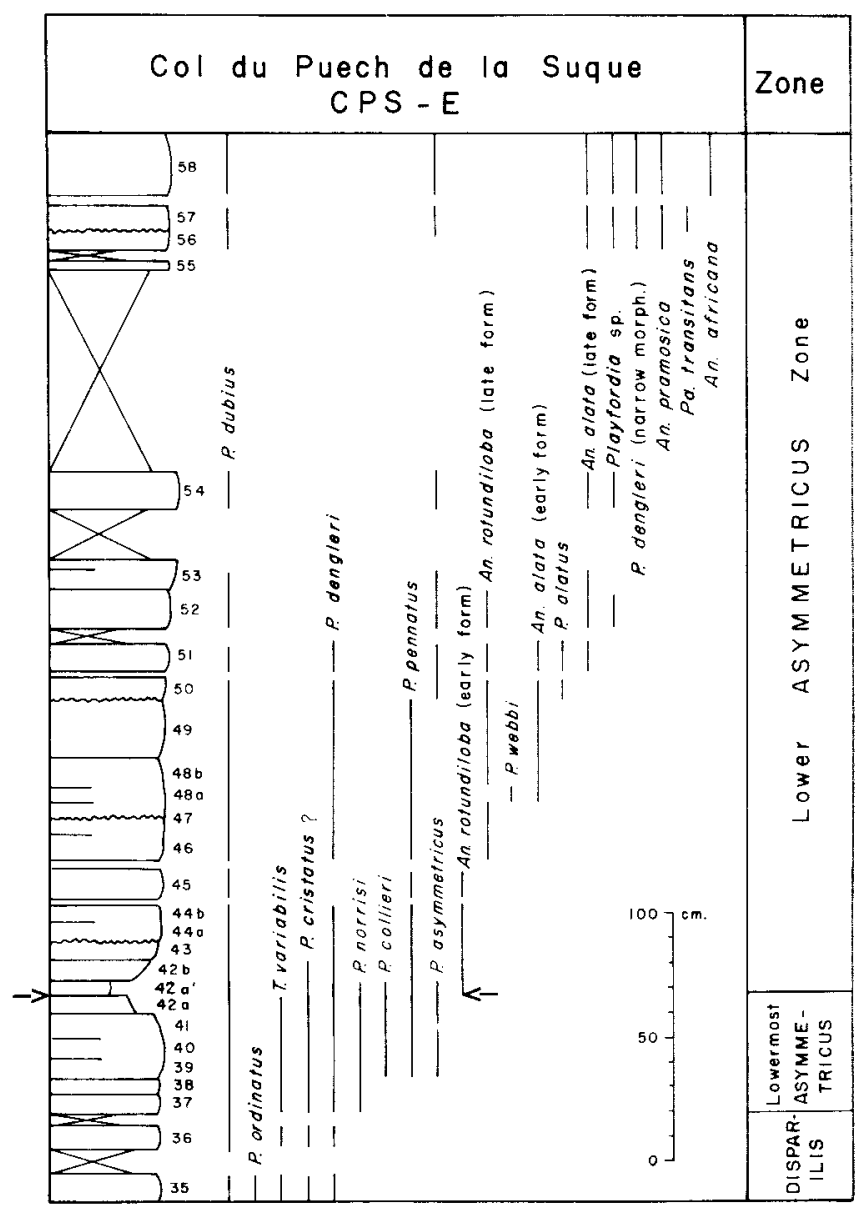

Figure 4: Ranges of conodont species from the disparilis zone to a position near the top of the Lower asymmetricus Zone at Col du Puech de la Suque section $E$. Generic abbreviations are as follows: $P$. = Polygnathus, $T_{0}=$ Tortodus, $A n .=$ Ancyrodella and $\mathrm{Pa} .=$ Palmatolepis. From Klapper (1985, Fig. 2).

The new level for the Middle/Upper Devonian boundary falls within the old goniatite zone of Pharciceras lunulicosta (formerly equal to zone Ia on Figure 5), the base of which represents one of the major breaks in goniatite evolution. Recent work on the faunal subdivision of the old Lunulicosta Zone has enabled correlation with the new boundary. At the Montagne Noire stratotype section pharciceratids are common below the boundary but rarer above. Probeloceras first appears low in the Lower asymmetricus Zone at Col du Puech de la Suque section $\mathrm{E}$, within the first interval described above (Fig. 5). Koenenites, represented by $\mathrm{K}$. lamellosus and $K$. sp., appears high in the zone and in the fifth interval at the same section (House and others, 1985, Fig. 13), and Hoeninghausia is known a little higher at La Serre. Probably most significant is the new form Petteroceras feisti, which occurs in the lowest part of the Lower asymmetricus Zone. This appears to represent a stablelobed descendant of Petteroceras errans, known in North Africa from rather older levels.

The stratotype section in the Montagne Noire is thin and reduced. In the thicker New York sequence a more detailed goniatite succession is known (Kirchgasser and House, 1981, Kirchgasser et al, in Ziegler and Werner, 1985), which shows the entry of Koenenites and Probeloceras in the first interval of the Lower asymmetricus Zone and also Hoeninghausia in the upper interval (House and Kirchgasser, unpublished), thus confirming the sequence of the stratotype. 
In addition to conodonts and goniatites, trilobites, tentaculites, and brachiopods (at some levels) occur in the Montagne Noire sections shown in Figure 3. These latter three groups are presently under study.

\section{Discussion}

At the 1982 Subcommission meeting, when the Lower asymmetricus Boundary was adopted as the biostratigraphic level for the Series boundary by a nearly unanimous vote of the attending titular members, it was also agreed that the boundary stratotype section should be selected in a pelagic facies sequence. Thus, the type Frasnian section in the Ardennes, which is in a neritic facies sequence, was suggested as a possible candidate for an auxiliary stratotype.

In addition to the pelagic sequences in the Montagne Noire, those in southern Moroceo were also proposed as candidates for the boundary stratotype at the 1983 and 1985 meetings of the Devonian Subcommission. The Morocean sections were given serious consideration because they represent demonstrably better exposures and contain more abundant and better preserved goniatites at many levels, as compared with those in the Montagne Noire. Nonetheless, all of the considered sections in

Morocco (Bensaid et al., in Ziegler and Werner, 1985) have deficiencies in the conodont and/or goniatite record at the apparent position of the lower boundary of the Lower asymmetricus Zone.

For example, in the condensed bed just above the boundary at Bou Tehrafine I (Bensaid et al., ibid, Fig. 2) A. rotundiloba occurs together with A. alata at the base of the bed and A. pramosica first occurs only slightly above the base. This indicates that the lower part of the Lower asymmetricus Zone is not represented, according to the sequence developed in the Montagne Noire. Another section, El Atrous (Bensaid et al., ibid, Fig. 6) has an evidently consequential gap in the conodont sequence between the highest sample of the Lowermost asymmetricus Zone and the lowest productive sample of the Lower asymmetricus Zone, which again contains A. alata indicating that it does not represent the base of the zone. Furthermore, the section lacks goniatites in the Lower asymmetricus Zone.

Dr. G. Klapper is Professor of Geology at the University of Iowa (Iowa City, Iowa 52242, U.S.A.). His research concentrates on Silurian and Devonian conodont taxonomy and biostratigraphy, with special current emphasis on the Frasnian sequence in the Montagne Noire, and its correlation with the similar sequence in western Alberta, Canada. He is a Titular Member of the Subcommission on Devonian Stratigraphy.

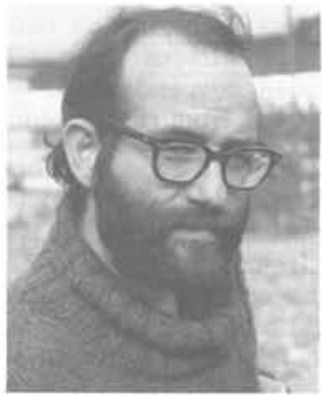

Professor M. House is Head of the Department of Geology at the University of Hull (North Humberside, HU6 7RX, U.K.). He is a Past President of the Palaeontological Association and the Systematics Association. His researches have mainly concentrated on midPalaeozoic correlation, biostratigraphy, and palaeogeography, especially using ammonoids. $\mathrm{He}$ is a Titular Member of the Subcommission on Devonian Stratigraphy.
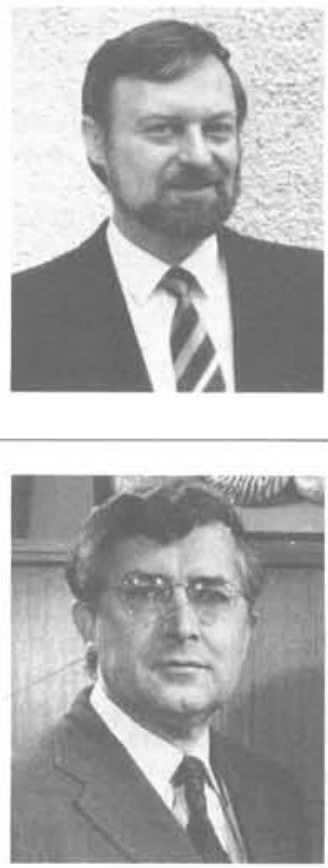
The precise Point of the GSSP is defined in the foregoing at the base of Bed $42 \mathrm{a}^{\prime}$ (Fig. 2B; note the tick above the $a$ in the Bed number - an essential feature). Bed $4 \overline{2}^{\prime} a^{\prime}$ is a stratum $5 \mathrm{~cm}$ thick, part of a pelagic calcilutite succession. There is no obvious hiatus, hardground or sampling gap associated with this part of the succession and the GSSP coincides with the first appearance of Ancyrodella rotundiloba (Bryant). The first arrival datum (FAD) of this conodont species is the biostratigraphic guidance used in the selection of an appropriate GSSP (a point in rock), which is referred to as the basal Lower asymmetricus Boundary. The Lower asymmetricus zone is a subdivision of the conodont standard zonation that was established by ziegler (1962, 1971).

The underlying zone of the Middle Devonian Series and of the Givetian Stage is known as the Lowermost asymmetricus zone. The GSSP at the base of the Frasnian stage (described above) automatically defines, in line with ICS procedure (Cowie et al., 1986, p. 8), the top of the Middle Devonian Series, also the top of the Giventian Stage as well as the top of the Lowermost asymmetricus Zone.

Voting ('titular') members of the Subcommission on Devonian stratigraphy accepted this GSSP by a vote YES - 16. NO - 3, No opinion 1 , no response 1 . The International Commission on stratigraphy approved this definition with a vote of YES - 19, NO - 1, Abstentions 2. Ratification by the Executive of IUGS was granted in February 1987.

A global overview of Devonian Subcommission boundary decisions and their wide usefulness has been edited by $\mathrm{z}$ iegler and werner (1985).

The brief check-list for criteria (1-9) used in selection of a Global Stratotype section and Point
(GSSP) under ICS Guidelines (Cowie et al., 1986, p. 10) is here considered for this GSSP. Other publications deal with the topic in detail.

1. "Explicit motivation for the preference": Ancyrodella rotundiloba is an easily recognizable species that is part of a well-documented phylogeny and predecessors and transitional forms permit additional means of identification of the Lower asymmetricus zone. A. rotundiloba is a widespread taxon ecologically, occurring widely in both neritic and pelagic facies and is well known from all relevant Devonian areas in the wor ld.

2. "Correlation on a global scale": in addition to A. rotundiloba, other conodonts, goniatites, trilobites, tentaculitids and brachiopods occur and global correlation seems assured.

$3-6,8$. The criteria, 3. "completeness of exposure," 4. "adequate thickness of sediments," 5. "abundance of well preserved fossils," 6. "favourable facies for widespread correlation" and 8. "amenability to magnetostratigraphy and geochronometry" are all satisfied by the GSSP. Comment is needed on criteria 7 and 9, however.

7. "Freedom from structural complication and metamorphism." The unmetamorphosed succession is overturned, but mapping and section-measuring remove any doubt as to the true succession and the straightforward interpretation of the lithostratigraphy.

9. "Accessibility and conservation." There is no problem of access to the section, either politically or logistically. It is adjacent to a vineyard owned by the commune of $s t$. Nazaire-deLadarez, and permission to visit the section can be granted, and conservation/preservation is at present assured.

\section{References}

Bultynck, P., 1982a. The Ancyrodella binodosa - A. rotundiloba rotundiloba transition, a datum-level for correlation of the Givetian-Frasnian boundary. In: Bigey, F., and others (eds.), Papers on the Frasnian-Givetian boundary, Geological Survey of Belgium, Brussels, p. 17-33.

Bultynck, P., 1982b. Conodont succession and general faunal distribution across the Givetian-Frasnian boundary beds in the type area; with contributions by L. Jacobs. In: Bigey, F. and others (eds.), Papers on the Frasnian-Givetian boundary, Geological Survey of Belgium, Brussels, p. 34-59.

Cowie, J.W., Ziegler, W., Boucot, A.J., Bassett, M.G. and Remane, J., 1986. Guidelines and statutes of the International Commission on Stratigraphy (ICS). Courier Forschungsinstitut Senckenberg, Frankfurt am Main, v. 83, p. 1-14.

Feist, R. and Klapper, G., 1985. Stratigraphy and conodonts in pelagic sequences across the Viddle-Upper Devonian boundary, Montagne Noire, France. Palaeontographica, Abteilung A, Band 188, no. 1-3, p. 1-18.

House, M.R., Kirchgasser, W.T., Price, J.D. and Wade, G., 1985. Goniatites from Frasnian (Upper Devonian) and adjacent strata of the Montagne Noire, Hercynica, v. 1, no. 1, p. 1-21.

Kirchgasser, W.T. and House, M.R., 1981. Upper Devonian goniatite biostratigraphy. In: Oliver, W.A., Jr. and Klapper,
G. (eds.), Devonian biostratigraphy of New York, part $I$. IUGS Subcommission on Devonian Stratigraphy, Washington, p. $39-55$.

Klapper, G., 1985. Sequence in conodont genus Ancyrodella in Lower asymmetricus Zone (earliest Frasnian, Upper Devonian) of the Montagne Noire, France. Palaeontographica, Abteilung A, Band 188, no. 1-3, p. 19-34.

Uyeno, T.T., 1974. Conodonts of the Waterways Formation (Upper Devonian) of northeastern and central Alberta. Geological Survey of Canada Bulletin no. 232, 93p.

Ziegler, W., 1962. Taxionomie und Phylogenie Oberdevonischer Conodonten und ihre stratigraphische Bedeutung. Abhandlungen des Hessischen Landesamtes fur Bodenforschung, Heft $38,166 \mathrm{p}$.

Ziegler, W., 1971. Conodont stratigraphy of the European Devonian. In: Sweet, W.C. and Bergström, S.M. (eds.), Conodont Biostratigraphy. Geological Society of America Memoir 127, p. 227-284.

Ziegler, W. and Klapper, G., 1985. Stages of the Devonian System. Episodes, v. 8, no. 2, p. 104-109.

Ziegler, W. and Werner, R. (eds.), 1985. Devonian Series Boundaries - results of world-wide studies. Courier Forschungsinstitut Senckenberg, Frankfurt am Main, v. 75, 416p. 